12-7-2009

\title{
Corporate Social Performance: Reporting Roundtable
}

Poonam Puri

Osgoode Hall Law School of York University, ppuri@osgoode.yorku.ca

Edward J. Waitzer

Osgoode Hall Law School of York University, ewaitzer@osgoode.yorku.ca

Kevin Ranney

Michael Torrance

Follow this and additional works at: http:// digitalcommons.osgoode.yorku.ca/reports

\section{Repository Citation}

Puri, Poonam; Waitzer, Edward J.; Ranney, Kevin; and Torrance, Michael, "Corporate Social Performance: Reporting Roundtable" (2009). Commissioned Reports and Studies. Paper 1.

http://digitalcommons.osgoode.yorku.ca/reports/1 


\section{Corporate Social Performance: Reporting Roundtable}

\section{Consultation Paper}

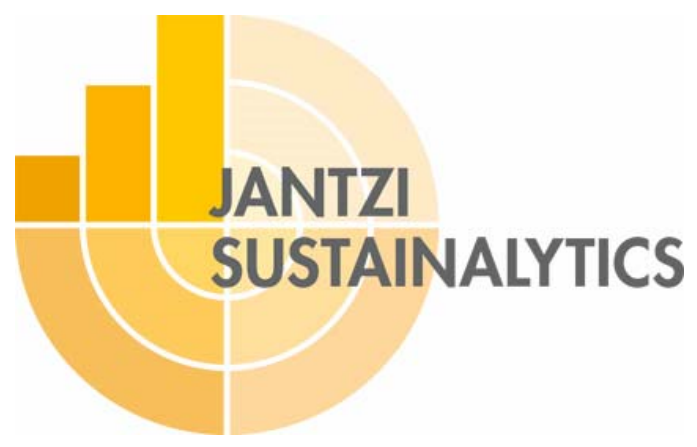

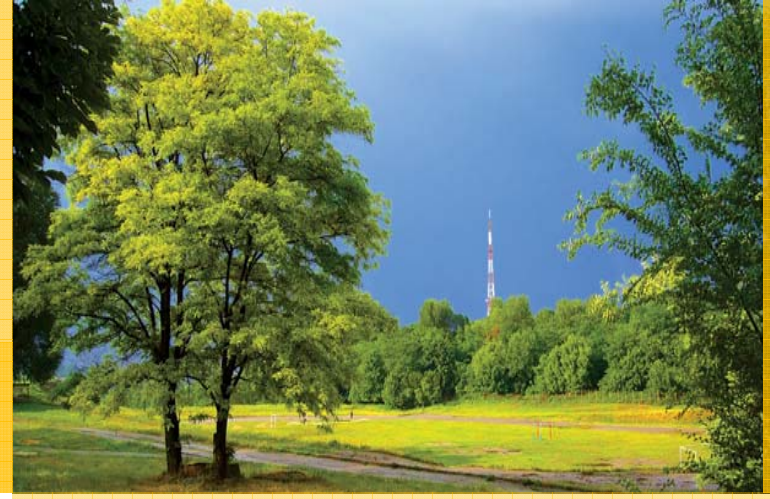

Presented by:

Hennick Centre for Business and Law at York University

AND

Jantzi-Sustainalytics

Sponsored by:

ACCA

Association of Chartered Certified Accountants 


\section{Background}

\subsection{Purpose of Consultation}

The purpose of this consultation (the "Consultation") is to elicit the views of informed stakeholders in a review of reporting and disclosure requirements under Ontario securities legislation for corporate "social" performance (hereinafter referred to as "corporate social performance"), as that concept is defined in section 1.4 below. In particular, the Consultation's participants are asked to consider whether existing reporting and disclosure requirements on corporate social performance are adequate. If change is advisable, the question becomes what regulatory or other measures merit consideration.

\subsection{Background on the Initiative}

The Consultation is in response to a private member's resolution introduced by the Honorable Laurel Broten (Etobicoke-Lakeshore), ${ }^{1}$ and passed unanimously by the Ontario Legislature (the "Resolution"). ${ }^{2}$ In part, the Resolution calls on the Ontario Securities Commission ("OSC") to conduct a consultation on corporate social responsibility ("CSR") and environmental, social and governance ("ESG") reporting standards, and to adopt an enhanced standardized reporting framework for both quantitative and qualitative social and environmental information to ensure that corporate disclosures are understandable, comparable, and outcome-focused. The Resolution called for a report, including policy recommendations, be submitted to the Minister of Finance.

\footnotetext{
${ }^{1}$ Now Minister of Children and Youth Services and Minister Responsible for Womens' Issues.

${ }^{2}$ For the complete text of the Resolution, see Appendix A.
} 
This will be the second of two consultations emerging from the Resolution. The first session, held on September 18, 2009, was organized by the OSC (with assistance from the Hennick Centre for Business and Law (the "Hennick Centre")) and focused on the areas of environmental and governance disclosure. The December 7, 2009 session will focus on disclosure and reporting with respect to corporate social performance. The Consultation is being organized by the Hennick Centre and Jantzi-Sustainalytics, with sponsorship from the Association of Chartered Certified Accountants. ${ }^{3}$

Copies of this Consultation Paper will be made available to interested parties who might not be able to participate in the Consultation, for their comment and input into the Consultation process.

\subsection{Mandate and Project Scope}

The Consultation process will involve the following:

- Review of existing disclosure requirements under Ontario securities law for reporting issuers (other than investment funds) regarding corporate social performance;

- A roundtable meeting with stakeholders on the issue of corporate social performance reporting;

- Preparation of a report including recommendations to the Minister of Finance regarding "next steps" to enhance corporate social performance reporting and disclosure.

The Consultation is guided by the following framework questions:

- What information on corporate social performance do investors and other stakeholders want and need?

\footnotetext{
${ }^{3}$ The authors of this paper wish to thank Eugene Ellmen of the Social Investment Organization, Paul Costello of ACCA, and Priya Bala Miller of SHARE for their feedback on a draft of this paper.
} 
- What are the challenges and benefits associated with providing information on corporate social performance?

- Are existing disclosure requirements under Ontario securities relating to corporate social performance consistent with international requirements and standards?

- Are the OSC's continuous disclosure reviews of corporate social performance matters adequate to support compliance with the existing disclosure requirements?

- What are the challenges in operationalizing and enforcing disclosure requirements with respect to corporate social performance?

The recommendations that flow from the Consultation will take into account:

- The OSC's mandate of providing protection to investors from unfair, improper or fraudulent practices and fostering fair and efficient capital markets and public confidence in capital markets;

- The ongoing role of the OSC and other securities regulators in defining materiality standards for corporate disclosure and their emerging role in addressing issues of systemic market risk that may be affected by corporate social performance and which could be mitigated by disclosure and reporting on such issues;

- Other legal and policy considerations beyond those of traditional securities regulatory frameworks in respect of which corporate social performance disclosure and reporting may be relevant.

In addition, the recommendations will have regard to the following principles:

- Capital market and regulatory efficacy is supported by the harmonization and coordination of securities regulation regimes; 
- Costs and other restrictions imposed on market participants should be proportionate to regulatory objectives sought.

\section{Questions:}

- Are the framework questions appropriate?

- What additional issues and principles ought to inform the Consultation?

\subsection{The Scope of Corporate Social Performance}

Corporate social performance includes consideration of a broad range of positive and negative effects of corporate behaviour on various stakeholders. Though not exhaustive, the following is a list of stakeholders and issue areas that are encompassed by corporate social performance:

- Community and Society - includes the direct effect of corporate behavior on local communities (often including First Nations communities), corporate engagement and consultation with local communities, contributions to local community development, philanthropy, influence on public policy and political contributions.

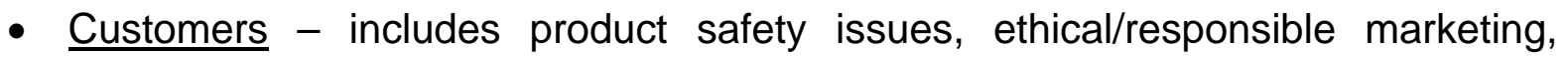
advertising practices and fair treatment of customers.

- Employees - includes employee training and development, employment equity and diversity, occupational health and safety, working conditions, labour relations and employee rights (including freedom of association and collective bargaining).

- Supply chain - including labour rights and working conditions in the supply chain.

- Business ethics - including considerations of anti-trust/anti-competitive behavior, bribery and corruption.

- Human Rights - including exposure to and potential complicity in human rights abuses in countries with poor human rights records or conflict zones. 
In each of these areas, reporting and disclosure may include information on a company's policies, management and information systems, and initiatives to manage exposure or capitalize on opportunities in these areas. Reporting and disclosure may also include information on any specific concerns, challenges and opportunities that the company has, or may face, and how it manages risk in these areas as well as relevant metrics for measuring performance outcomes.

\section{Questions:}

- What other issues should be encompassed by corporate social performance? 


\section{Relevance of Corporate Social Performance Reporting}

\subsection{Materiality of Corporate Social Performance for Investors}

There is growing recognition in the investment community of the relevance of corporate social performance to the management of investment portfolios. At the same time, long-term investors have become increasingly concerned about systemic risk which, for some, is as or more important than sectoral or firm specific risk assessment. As evidence of these trends, there has been a dramatic increase in demand for such disclosure and corporate social performance related financial research products (e.g., information aggregators, research, rating services, stock exchange indices and related financial instruments). ${ }^{4}$

Many shareholder activists have recognized the relevance of social performance, along with environmental and governance performance. Consequently, improved disclosure on these issues has been a major focus of shareholder engagement initiatives. Such engagement can take a variety of forms, including letter writing, meetings with management, and shareholder resolutions.

Hundreds of shareholder resolutions are filed every year in Canada and the U.S. addressing a variety of ESG issues. According to the Shareholders Association for Research and Education ("SHARE"), between the 2000 and 2009 proxy voting seasons there were 67 resolutions filed in Canada addressing social aspects of corporate performance, with key areas including community engagement, indigenous rights,

\footnotetext{
${ }^{4}$ See, for example, H. Shafer, J. Beer, J. Zenker and P. Fernandes, "Who is in Corporate Social Responsibility Rating?", (2006) Bertelsmann Foundation.
} 
human rights, employees issues, and customer issues. Among these resolutions, 44 had a component that addressed or requested enhanced reporting on these issues.

There has been a substantial amount of research into the materiality of ESG performance for investors. In 2004, the Asset Management Working Group ("AMWG") of the United Nations Environment Programme ("UNEP") Finance Initiative ("Fl") published a report entitled The Materiality of Social, Environmental and Corporate Governance Issues to Equity Pricing, composed of research conducted by nine international brokerage firms. The overarching conclusion of the report was that environmental, social and corporate governance issues affect long-term shareholder value, and in some cases those effects may be "profound". 5

In 2006, the AMWG published a second report on the issue of materiality. Entitled Show Me The Money: Linking Environmental, Social and Governance Issues to Company Value, the report was a compilation of 12 studies conducted by 10 international brokerage firms on the financial effects of ESG across various sectors. Its key findings were that:

1. ESG issues are material - there is robust evidence that ESG issues affect shareholder value in both the short and long term.

2. The impact of ESG issues on share price can be valued and quantified.

3. Key material ESG issues are becoming apparent, and their importance can vary between sectors.

In October 2007, Mercer and the AMWG published Demystifying Responsible Investment Performance. ${ }^{6}$ The report surveyed academic research into the relationship

\footnotetext{
5 "The Materiality of Social, Environmental and Corporate Governance Issues to Equity Pricing" (2004), online: UNEP FI: Work Streams, AMWG < http://www.unepfi.org/work streams/investment/amwg/>.

6 “Demystifying Responsible Investment Performance" (2007), online: UNEP FI: Workstreams, AMWG $<$ http://www.unepfi.org/publications/investment/index.html>.
} 
between ESG issues and financial performance. In November 2009, Mercer released an updated report, Shedding Light on Responsible Investment. ${ }^{7}$ Pooling the results together with the 2007 report, 36 academic studies were surveyed, of which 20 show evidence of a positive relationship between ESG factors and financial performance, while only three show evidence of a negative relationship. The report also focuses on the need to develop comparable and reliable standards in order to "mainstream" the integration of ESG into investment processes.

\section{The Materiality of Corporate Social Performance - Example \#1 - Meridian Gold and the Esquel Project}

Meridian Gold Inc. acquired the Esquel gold property in Argentina in 2002 and developed a plan to construct an open-pit gold mine nine kilometres from Esquel, a city of 30,000 inhabitants. The company failed to implement mechanisms and processes to engage effectively with local communities or to respond to growing concerns over the potential impacts of the mine.

In February 2003, in response to growing opposition to the mine, the mayor authorized a public referendum on the mine's development, which was held the following month. About $75 \%$ of eligible voters participated in the vote, with $81 \%$ voting against the proposed mine. As a result, the company suspended operations.

In the first half of 2003 Meridian's share price fell sharply, driven to a large degree by problems surrounding the Esquel project. In early 2006, as required by accounting regulations, the company wrote down the value of the Esquel property to its fair commercial value without mineral resources, a write-down valued at US \$379 million. As a result of the write-down the company reported experiencing a net loss US \$346.4 million for fiscal year 2005.

See Steven Herz, Antonida Vina and Jonathan Sohn, "Development Without Conflict: The Business Case for Community Consent" (2007) World Resources Institute at 31.

In 2005, former United Nations ("UN") Secretary General Kofi Annan founded the UN Principles for Responsible Investment (the "PRI"). The PRI were developed in response to the work of the AMWG and, more generally, a growing view among investment professionals that ESG issues can affect the performance of investment portfolios, such that appropriate consideration of such issues is necessary to fulfill the fiduciary duty of investment managers. Signatories pledged to incorporate ESG issues into investment analysis and decision making processes, to engage with companies on their ESG performance, and to seek disclosure on ESG issues by the entities in which they invest.

\footnotetext{
${ }^{7}$ Mercer White Paper, "Shedding Light on Responsible Performance" (2009), online at: $<$ www.mercer.com/ri $>$.
} 
There are currently 633 signatories to the PRI, including asset owners, investment managers and professional service partners, representing over US\$18 trillion of total assets under management. ${ }^{8} 85 \%$ of signatories have policies that make reference to responsible investment or ESG issues and 63\% of asset owners now include responsible investment or ESG elements in contractual relationships with external managers.

Disclosure of ESG performance is a significant focus of the PRI. In its 2009 report on signatories' progress in implementing the principles, the PRI reported that $90 \%$ of signatories had engaged with companies in developed markets regarding their need for standardized ESG reporting. ${ }^{9}$ According to the same report, a number of signatories have cited a lack of disclosure on ESG issues as a key barrier to their implementation of the PRI.

The Australian Council of Super Investors ("ACSI") recently released guidelines entitled "A guide for superannuation trustees on the consideration of environmental, social and governance risks in listed companies" and "A guide for fund managers and consultants on the consideration of environmental, social and governance risks in listed companies". ACSI indicated its belief that good governance requires boards to consider and manage such risks and that consideration of ESG factors in investment decision making is essential. $^{10}$

Another major initiative that emerged from the growing recognition of the materiality of ESG performance is the Enhanced Analytics Initiative ("EAI"). Founded in 2004, the EAI was an international collaboration of institutional investors that aimed to address the absence of quality research on the impact of extra-financial issues, including ESG

\footnotetext{
${ }^{8}$ Online: Principles for Responsible Investing < $\underline{w w w . u n p r i . o r g}>$.

9 "Report on Progress 2009: A review of signatories' progress and guidance on implementation" (2009), Online: Principles for Responsible Investing < $<w w$.unpri.org $>$ at p. 3.

${ }^{10}$ Media Release (October 12, 2009), online: <www.acsi.org.au $>$.
} 
issues, on long-term investment value. EAl members committed to allocating at least

$5 \%$ of their brokerage commissions to such research. As of mid-2008 EAl members

represented total assets under management of about US $\$ 2.4$ trillion. ${ }^{11}$

\section{Materiality of Corporate Social Performance - Example \#2 - Talisman Energy and Sudan}

Between October 1998 and March 2003, Talisman Energy Inc. held a 25\% interest in the Greater Nile Oil Project (GNPOC) in Sudan. GNPOC's project included three blocks in the Muglad basin in the Western Upper Nile region of southern Sudan and a 500-kilometre pipeline that runs from the oil fields to Port Sudan on the Red Sea. Production began in 1999.

Northern and southern Sudan had been locked in conflict for decades, and control over areas in the GNPOC concession was divided between the government of Sudan and two rebel movements: the Sudan People's Liberation Army (SPLA) and the Sudan People's Democratic Force (SPDF).During the civil war, widespread abuses of human rights occurred as both government forces and armed opposition groups indiscriminately and directly targeted civilians and reportedly carried out extrajudicial executions in the context of the civil war. The civil war cost the lives of almost two million people and resulted in the displacement of a further 4.5 million. During the war, there were numerous occasions in which Khartoum used the denial of food and humanitarian aid as a weapon of war.

During its time operating in Sudan, allegations emerged of links between the development of oil by Talisman/GNPOC and the abuse of human rights. It was alleged, for example, that there was evidence that the Government of Sudan, in an effort to secure land for oil development, had forcibly and violently displaced people from areas within and bordering the GNPOC concession since Talisman joined the partnership.While senior management at Talisman Energy emphasized that the company's overall impact on the country was positive and that claims of human rights abuses were unsubstantiated, a broadly-based, international campaign grew in opposition to the company's involvement in Sudan.

The impact of the major controversy over Talisman's operations in Sudan was clear. Prior to the company's investment its shares had sold at a $20 \%$ premium (to net asset value). Subsequent to the emergence of the controversy over its operations it shares were estimated to be trading at a 10 to $20 \%$ discount. Almost immediately after its divestment in March 2003, the company's share price recovered.

Stephen J. Kobrin, "Oil and Politics: Talisman Energy and Sudan", International Law and Politics, Vol. 36:425 2004.

The foregoing section provides evidence of the materiality of corporate social performance and ESG for investors. As the next section will consider, transparency on corporate social performance may also relate to broader policy interests in effective corporate governance, since it provides a tool for companies to better understand stakeholder concerns, and for stakeholders to better understand corporate practices,

11 In October 2008 the EAI and the PRI merged under the PRI banner and formed the PRI Enhanced Research Portal, which is an "effort to stimulate increased volumes of timely and transparent analysis covering ESG issues and their implications for companies, sectors and markets." 
thereby facilitating decision making that better aligns the interests of the corporation and society.

\subsection{Macro Policy Rationale for Corporate Social Performance Reporting}

Financial markets have demonstrated the risk of misaligned incentives that may lead corporations to engage in risky activities that are adverse to the interests of long-term investors and society. The classic Berle-Means model of the corporation identified such conflicts, particularly the conflict between the separation of ownership from control and the role of the corporate director as mediator of varied social interests. ${ }^{12}$ Securitization and fund management are forms of financial intermediation that result in the separation of "ownership from ownership", meaning that the ultimate beneficial owners of securities do not assume responsibility for corporate conduct. ${ }^{13}$

Despite (or in response to) such conflicts, the majority of major global companies have adopted some form of ESG reporting into their corporate governance practices. A recent survey of the reporting practices of the 250 largest corporations in the world indicated the following most-cited motivations for social reporting (in order): ${ }^{14}$

Ethical considerations

Economic considerations

Reputation or brand

Innovation and learning

Risk management or risk reduction

Strengthened supplier relationships
Employee motivation

$69 \%$
$68 \%$
$55 \%$
$55 \%$
$52 \%$
$35 \%$
$32 \%$

${ }^{12}$ A. Berle \& G. Means, The Modern Corporation and Private Property (New York: Harcourt Brace, 1967).

${ }^{13}$ Leo E. Strine Jr., "Why Excessive Risk-Taking is not Unexpected" (October 5, 2009), online: New York Times Deal Book Dialogue <http://dealbook.blogs.nytimes.com/2009/10/05/dealbook-dialogue-leostrine/>.

14 "International Survey of Corporate Responsibility Reporting" (2009), online: KPMG < www.kpmg.com>. 
Access to capital or increased shareholder value Market position (market share) improvement $29 \%$ Improved relationships with governmental authorities Cost savings
$22 \%$

$21 \%$

$17 \%$

Implicit in this trend towards enhanced disclosure is a perception that stakeholder identification and engagement is important to corporate success. In this sense, corporate social performance reporting has become an important management process. It is seen as an instrument by which corporations can constructively engage with stakeholders, raise awareness and improve decision-making.

\section{Materiality of Corporate Social Performance - Example \#3 - Northgate Minerals and the Kemess North Project}

A third case demonstrating the materiality of social performance involves Northgate Minerals Corporation and its planned Kemess North Project in British Columbia, located on land claimed by the Tse Keh Nay and the Gitxsan House of Nii Kyap First Nations. Since 2004, the First Nations expressed serious concerns regarding the potential negative impacts of the project on the environment and on their ability to fish, hunt, and continue their traditional spiritual practices near the proposed development site. They were particularly concerned with what they alleged was an inadequate consultation process regarding the company's development plans.

In September 2007, a Joint Review Panel concluded that the mine "in its present form" would not be in the public interest. The panel stated that any economic and social benefits from the project were outweighed by its long-term risks to the environment and by its social and cultural impacts on Aboriginal people. It recommended to federal and provincial environment Ministers that the project not be permitted.

Following the announcement, Northgate Mineral's share price fell by 45 cents to $\$ 2.78$, reducing the value of the company by $\$ 740$ million.

In November 2007, the company announced that it was writing off its investment in the Kemess North project "as a result of the Panel's report." (See Northgate Minerals Corporation, News Release, Nov. 5, 2007.)

It is in this context that various supranational non-governmental standard setters considering the issue of social reporting have embraced reporting frameworks that go beyond short-term impacts on the market valuation of corporate securities. For example, the AccountAbility AA1000 framework, discussed below in section 5.2.4, uses the principle of "inclusivity" which is defined by an organization's commitment to identify, 
engage with and respond to stakeholders, and account for performance. ${ }^{15}$ Through $^{1}$ engagement with stakeholders, companies are better able to determine "materiality" (defined more broadly than effect on short-term market price) based on an assessment of an issue's relevance and importance to legitimate stakeholders.

The forthcoming International Standards Organization ("ISO") 26000 standard, discussed below in section 5.2.5, focuses on integrating seven core ESG subjects throughout an organization: governance, human rights, labour practices, environment, fair operating practices, consumer issues and community involvement/development. The ISO 26000 standard views internal and external communication as critical for:

- demonstrating accountability and transparency;

- $\quad$ helping to engage and create dialogue with stakeholders;

- addressing legal and other requirements for the disclosure of information related to social responsibility;

- showing how the organization is meeting its commitments on social responsibility and responding to the interests of stakeholders and expectations of society in general;

- raising awareness both within and outside the organization on its strategies and objectives, plans, performance and challenges for social responsibility;

- providing information about the impacts of the organization's activities, products and services, including details of how the impacts change over time;

- helping to engage and motivate employees and others to support the organization's activities in social responsibility;

- facilitating comparison with peer organizations, which can stimulate improvements in performance on social responsibility; and

- enhancing an organization's reputation to responsible action, openness, integrity and accountability, to strengthen stakeholders' trust in the organization.

15 "AA1000 Accountability Principles" (2008), online: AccountAbility <www.accountability21.net>. 
Social reporting has become a useful starting point for engaging with stakeholders, creating goodwill and a "safe space" for dialogue which, over time, informs internal decision-making. Such engagement provides a critical framework for assessing and managing risks and opportunities on a regular basis. This, in turn, can drive performance, enhance an organization's reputational franchise and relational capital and increase opportunities for collaboration.

For example, in recently launching their worldwide sustainable product index, the Chief Executive Officer of Walmart stated:

Customers want products that are more efficient, that last longer and perform better. And increasingly they want information about the entire life-cycle of a product so they can feel good about buying it. They want to know that the materials and the product are safe, that it was made well and that it was produced in a responsible way. We do not see this as a trend that will fade. High customer expectations are a permanent part of the future. ${ }^{16}$

In response, Walmart is surveying more than 100,000 suppliers around the world and is seeking to partner with others (suppliers, retailers, NGOs, governments and universities) to develop a global database of sustainability information on the life-cycle of products.

The collaboration extends beyond business-led initiatives for social reporting and engagement. Several countries, including Canada $^{17}$ and Denmark, ${ }^{18}$ have identified corporate social reporting as a cornerstone in building comparative and competitive social advantage on a national scale, by enhancing national as well as institutional

\footnotetext{
${ }^{16}$ Mike Duke (CEO of Walmart) prepared remarks in announcing Walmart's sustainable produce index, July 16, 2009.

${ }^{17}$ See section 4.4 .2 below.

18 "Reporting on Corporate Social Responsibility" (2009), online: Danish Commerce and Companies Agency $<$ www.csrgob.dk $>$.
} 
reputations, attracting employees, better meeting customer demands and contributing to the long-term legitimacy of market enterprise.

\section{Materiality of Employee Satisfaction - Example \#4 - Edmans Study}

Alex Edmans of the Wharton School conducted research on a specific aspect of social performance: employee satisfaction. His research, published in 2007, involved an analysis of the share price performance of companies on Fortune magazine's "Best Companies to Work For" list between 1998 and 2005. According to the Edmans study, an equal-weighted portfolio containing these companies outperformed the market even after adjusting for differences among the companies with respect to size, valuation, and momentum. Edmans found unexplained and statistically significant alpha of $+0.52 \%$ and, on the basis of his findings, concluded that "employee satisfaction is positively related to corporate performance...the findings imply that the market fails to incorporate intangible assets fully into stock valuations - even if the existence of such assets is verified by a widely respected survey."

Edmans, Alex. Does the Stock Market Fully Value Intangibles? Employee Satisfaction and Equity Prices. MIT Working Paper, 2007.

Financial statements "capture less than $20 \%$ of corporate risks and value creation potential, with the balance deriving from intangible factors such as human capital and resource sufficiency". ${ }^{19}$ It is in this context that social reporting can be understood to be critical, not just for investors but for a broader group of stakeholders, including:

- Employees - non-financial information is critical to defining an organizational culture, both for current employees and potential recruits;

- $\quad$ Consumers - as noted earlier, consumers drive demand and their expectations are rising; conversely, it has become apparent that consumers (and other stakeholders) take action against companies they do not trust; ${ }^{20}$

- $\quad$ Business Partners - corporations are increasingly moving beyond informing organizations in their value chains of their activities as a way to promote such relationships and moving towards using social reporting to engage business partners in finding solutions to social and environmental problems;

\footnotetext{
${ }^{19}$ EuroSIF (supported by the Federation of European Accountants) public policy position paper related to sustainable and responsible investment (April 14, 2009).

20 "2009 Edelman Trust Barometer" (2009), online: Edelman <http://www.edelman.com/trust/2009/>.
} 
- Governments and Regulatory Agencies - demonstrating positive societal contributions made by business is critical in striking the right balance in a market enterprise economy and ensuring the success of any particular corporation; and

- $\quad$ Civil Society Organizations - which are typically interested in detailed information relating to specific topics, challenging the depth and breadth of a corporation's social reporting.

Ultimately, engaging with these diverse stakeholders may facilitate corporate strategy. Building relationships and better understanding the corporate social impacts can facilitate identification and improved decision-making around such issues. Typically, telling the story demonstrates the relevance of sustainability and leads to positive behavioural change and greater integration of sustainability issues into corporate decision-making.

\section{Questions:}

- Are there other legitimate reasons for enhanced social reporting besides the interests of investors and the policy objectives discussed above?

- Do specific elements of social reporting require additional attention over others? 


\section{Challenges of Corporate Social Performance Disclosure}

While the investor and macro policy interests in greater transparency with respect to corporate social performance are compelling, there are legitimate concerns and challenges for issuers associated with enhanced disclosure requirements. Such concerns include:

- Costs: Enhanced disclosure requirements impose added costs on issuers. A salient issue is the extent to which enhanced disclosure requirements would apply to small and medium enterprises, or whether such requirements would be limited to larger issuers. Such concerns must be balanced by the interest in consistency and fairness between issuers in respect of disclosure obligations.

- Board Discretion: Regulatory oversight of any corporate activity brings with it the risk of impeding the freedom of boards and managers to make decisions in the best interests of the company. Companies may have legitimate reasons (such as cost, materiality etc.) for not committing corporate resources to reporting on corporate social performance. A related concern with prescriptive approaches to regulating social performance disclosure is that it could inhibit the ability of boards to respond to the identified interests and needs of stakeholders. In contrast, principled approaches, if too broad, could have limited effect in terms of enhancing disclosure.

- Competitive (Dis)Advantage: Enhanced corporate social performance transparency requirements could put Canadian issuers at a disadvantage to their international counterparts by imposing added constraints on Canadian companies operating abroad that may not apply to their competitors. 
The foregoing challenges are relevant to the question of whether enhanced corporate social performance disclosure requirements are desirable, and how such requirements should be formulated.

\section{Questions:}

- What other concerns exist for issuers in respect of enhanced disclosure requirements?

- Should differently situated companies be treated differently, or exempted from requirements altogether?

- Do the costs of enhanced disclosure outweigh the benefits?

- To what extent should requirements be prescriptive rather than based on principles?

- What other considerations should guide regulators in deciding whether and how to require enhanced disclosure of corporate social performance? 


\section{Legal and Governance Context}

The following sections review the broader regulatory and governance context within which the social reporting and disclosure debate takes place.

\subsection{Statutory and Fiduciary Duties}

The legal standards applicable to corporate directors and fund managers are relevant to the question of how the measurement and reporting of corporate social performance can factor into managerial or investment decisions.

\subsubsection{Duties of Corporate Directors}

The Canadian Business Corporations Act (the "CBCA") requires directors and officers of corporations to act in the "best interests of the corporation". A question has arisen in Canadian jurisprudence whether or to what extent this duty permits or necessitates consideration of the interests of stakeholders other than shareholders. In the case of Peoples v. Wise, the Supreme Court of Canada confirmed that it is legitimate for corporate directors to take into consideration a broad array of interest and factors when determining and acting in the best interests of the corporation, including shareholders, employees, suppliers, creditors, consumers, governments and the environment. In the more recent decision of BCE Inc. v. 1976 Debentureholders, the Supreme Court of Canada indicated that a board's consideration of conflicting interests should involve the ideal of the "responsible corporate citizen". It is clear that under Canadian corporate law boards may take into account CSR considerations, and in some circumstances may be required to do so. ${ }^{21}$

\footnotetext{
${ }^{21}$ Kerr, M. \& Janda, R. \& Pitts, C., Corporate Social Responsibility: A Legal Analysis (Canada: Lexis Nexis, 2009) at 187. ["Kerr, Janda, Pitts"] 


\subsubsection{Fiduciary Duties of Investment Managers}

While corporate directors are held to statutory standards of care, skill and loyalty, fund trustees are arguably subject to higher "fiduciary" standards including, for example, a duty of impartiality, which requires them to "identify, respect and balance the various interests" of different participant and beneficiary groups. ${ }^{22}$

The international understanding of investment manager fiduciary duties has been expanding to include the permissibility of ESG considerations when making investment decisions. This issue was the focus of a 2005 report entitled $A$ legal framework for the integration of environmental, social and governance issues into institutional investment as commissioned by the AMWG. The report, prepared by the international law firm Freshfields Bruckhaus Deringer, reviewed nine legal jurisdictions (including Australia, Canada, France, Germany, Italy, Japan, Spain, the United Kingdom, and the United States), and concluded that integrating ESG considerations into an investment analysis to more reliably predict financial performance is clearly permissible, and arguably required, as part of an investment manager's fiduciary duty in all reviewed jurisdictions. $^{23}$

An update to this report was released by the AMWG in July 2009. Entitled Fiduciary Responsibility: Legal and practical aspects of integrating environmental, social and governance issues into institutional investment, the report argues that "advisors to institutional investors have a duty to proactively raise ESG issues within the advice that they provide, and that a responsible investment option should be the default position." In a recent survey conducted for Investment \& Pensions Europe (IPE), about 70\% per cent of respondents - who collectively manage $€ 197.6 \mathrm{bn}$ in assets - believe that it is

\footnotetext{
${ }^{22}$ American Law Institute, 2003.

23 "A Legal Framework for the Integration of Environmental, Social and Governance Issues into Institutional Investment" (2005), online: UNEP FI Asset Management Working Group $<$ http://www.unepfi.org/fileadmin/documents/freshfields legal resp 20051123.pdf>>
}

\section{1|Hennick Centre for Business and Law}


the duty of trustees to consider ESG factors when making investment decisions and selecting managers. ${ }^{24}$

\subsection{Canadian Securities Law and Regulation}

Publicly listed Canadian companies are subject to provincial securities disclosure obligations. National Instrument 51-102 - Continuous Disclosure Obligations ("NI 51102") sets out the ongoing disclosure requirements of reporting issuers (other than investment funds). In addition, the Management Discussion and Analysis ("MD\&A") Form and the Annual Information Form ("AIF") guide the filings of issuers. Generally, the MD\&A and AIF direct companies to focus on the disclosure of "material information".

The Ontario Securities Act provides a definition of materiality that encompasses the "market impact" standard, which requires that information should be disclosed if it has the potential to move share price. A "material fact" is one that would reasonably be expected to have a significant effect on the market price or value of securities. A "material change" pertains to a change in the business, operations or capital of an issuing company, or decision to make such a change, that would reasonably be expected to have a significant effect on the market price or value of any securities of the issuer.

Other elements of securities regulation appear to adopt a different standard. For example, the instructions for Annual Information Form disclosures ${ }^{25}$ uses the "reasonable investor" standard of materiality. Under that standard, information is material if the decision of a reasonable investor to buy, sell or hold securities of a company would be influenced if the information was omitted or misstated.

Under either standard of materiality, the MD\&A Form should contain information that may not be fully reflected in financial statements, including a discussion of important

${ }^{24}$ Online: <http://www.responsible-investor.com/home/article/ri round up october 5/P1>.

${ }^{25}$ Form 51-102F2. 
trends and risks that have affected corporate performance or which are reasonably likely to affect it in future. An AIF should provide material information about the company and its business at a point in time in the context of its historical and possible future development, and describe the issuer, its operations and prospects, risks and other external factors that impact the company.

NI 51-102 specifically requires issuers to disclose in the AIF any environmental and health risks relating to the company or its business that would be most likely to influence an investor's decision to purchase its securities. NI 51-102 also requires that if a company has implemented social or environmental policies that are fundamental to its operations, it describe such policies and the steps it has taken to implement them. There does not, however, appear to be an obligation to make a statement where the issuer has not implemented social or environmental policies. ${ }^{26}$

\section{Questions:}

- Is there a need to redefine or clarify statutory standards for directors or fund managers?

- Is this securities law materiality standard sufficient to ensure adequate disclosure?

- If not, what regulatory changes should be introduced to enhance disclosure and reporting on corporate social performance?

\subsection{Non-Securities Oversight of Corporate Social Performance in Canada}

Aside from securities reporting obligations aimed at investors, Canadian companies may be required by law or regulation to disclose information and proactively develop policies and practices regarding corporate social performance in relation to other relevant stakeholders. Below are some examples of specific corporate social performance requirements that already exist in Ontario relating to employment standards, labour relations, occupational health and safety, human rights, and pay equity.

\footnotetext{
${ }^{26}$ Kerr, Janda, Pitts at 247. 


\subsubsection{Employment Standards}

Employment standards legislation in Ontario sets minimum expectations for employers in respect of employment terms and conditions and, in some instances, requires reporting and disclosure of employment related information to interested stakeholders. For example, the Ontario Employment Standards Act, 2001 (the "ESA") requires employers who intend to terminate more than 50 employees within a four-week period to file with the Ministry of Labour information concerning the economic circumstances surrounding the termination, whether alternatives to termination were considered, and whether any such alternatives were implemented by the company. ${ }^{27}$ The Ministry can request further information from the company and shares the filings with the Ministry of Training, Colleges and Universities for the purposes of providing a range of programs and services to help workers make a rapid and effective transition to new employment. Such information must also be posted in the workplace. Failure to report in accordance with the requirements of the ESA in a timely manner could prevent the company from carrying out the proposed terminations.

\subsubsection{Labour Relations}

Corporate employers may be required to disclose during collective bargaining any decisions that have been made that could have a significant impact upon the bargaining unit. This could include plant closures, planned relocations or layoffs. Failure to adequately disclose such information could constitute an unfair labour practice contrary to the Ontario Labour Relations Act, 1995. Collective agreement language may also specifically require companies to consult with unions when making decisions involving significant operational change that would affect members of the bargaining unit.

${ }^{27}$ ESA, s. 58. 


\subsubsection{Occupational Health and Safety}

The Occupational Health and Safety Act (the "OHSA") requires companies to be proactive and take "every reasonable precaution" to ensure the health and safety of employees and imposes liability on the directors of companies for the health and safety of employees. This necessitates evaluation of health and safety hazards, the proactive adoption of safety policies, practices, and procedures to mitigate the risks that they present. Certain practices and procedures are prescribed while others may be left up to individual companies to determine. As well, companies are required to establish joint health and safety committees composed of both company and employee representatives that may identify workplace hazards and facilitate the effectuation of health and safety practices. This creates a structured role for interested stakeholders in the health and safety practices of the company.

While public reporting is not typically part of such health and safety obligations, the requisite compliance monitoring processes necessitate the disclosure of policies and practices, performance history, and information respecting specific incidents. Where incidents occur, reporting requirements arise, both under the OHSA as well as the Ontario Workplace Safety and Insurance Act.

\subsubsection{Human Rights}

Companies are expected to take a proactive approach in addressing human rights issues in relation to their stakeholders, particularly employees, under the Ontario Human Rights Code (the "Code"). The Code requires employers to ensure that employment practices do not result in discrimination on the basis of protected grounds such as gender, race, or disability. The Code does not directly require companies to publicly report on human rights practices, but such practices may be reviewed in the course of litigation arising under the Code. 


\subsubsection{Pay Equity}

The Pay Equity Act may require corporate employers to implement plans that address gender bias in pay scales, and report results to employees, workplace unions and governmental authorities. Compliance will often necessitate posting pay equity plans in the workplace as well as sharing such plans with unions and governmental authorities.

\section{Questions:}

- Should compliance with such issue-specific regulatory requirements be the subject of enhanced corporate social performance disclosure?

- Are the current disclosure and reporting obligations of these issue specific regulatory regimes adequate to meet the legitimate needs of relevant stakeholders?

\subsection{Sector Specific CSR and Reporting Requirements in Canada}

\subsubsection{Public Accountability Statements}

Regulated financial institutions with over $\$ 1$ billion in equity are specifically required to publish annually a "Public Accountability Statement" ("PAS") describing their contributions and that of their affiliates, to the Canadian economy and society. The PAS reporting requirement arises from the Bank Act, the Insurance Companies Act, and the Trust and Loan Companies Act. Regulations to these federal statutes prescribe the contents of PAS reports and the timing of their publication. While not required to do so, PAS reports often go "beyond compliance" and report on matters relating to negative, as well as positive, impacts of corporate activities on the Canadian economy and society. ${ }^{28}$

\section{Questions:}

- Should the PAS approach be extended to other issuers?

\footnotetext{
${ }^{28}$ Kerr, Janda, Pitts at 249. 


\subsubsection{Federal CSR Strategy for the Canadian International Extractive Sector}

In March of 2009 the Government of Canada introduced a new policy entitled Building the Canadian Advantage: A CSR Strategy for the Canadian International Extractive Sector (the "CSR Strategy"). The CSR Strategy was the culmination of a series of national roundtables ("Roundtables"), led by the Department of Foreign Affairs and International Trade, on CSR issues in the mining, oil and gas sectors and their operations in developing countries. The objective of these Roundtables was to examine measures that could be taken to position Canadian extractive sector companies operating in developing countries to meet or exceed leading international CSR standards and best practices.

Four policy initiatives have been announced by the Canadian Government as part of the CSR Strategy:

1) establishment of a "CSR Counselor" office to act as a neutral, impartial and objective reviewer of requests to undertake informal mediation and fact-finding related to the activities of Canadian extractive companies, in Canada or abroad. The first CSR Counselor was appointed in October of 2009;

2) creation of a new centre of excellence to be housed within the Canadian Institute of Mining, Metallurgy and Petroleum;

3) provision of ongoing assistance from the Canadian International Development Agency to help foreign countries develop their capacity to manage natural resources; and

4) promotion of internationally recognized, voluntary guidelines for CSR performance and reporting.

It is not yet clear the extent to which these policy objectives will entail regulation, or how existing securities or other disclosure and reporting rules may be affected in the 
implementation of the CSR Strategy. It should be noted that certain recommendations from the Roundtables are not part of the current CSR Strategy, including the withholding of government services, such as financial and insurance support provided by Export Development Canada, from companies in serious violation of CSR standards, or mandatory disclosure by federally regulated pension funds of the extent to which they utilize corporate social performance metrics in making investment decisions. ${ }^{29}$

\section{Questions:}

- Does the CSR Strategy reflect a trend towards regulatory or legislative oversight of corporate social performance?

- Should the CSR Strategy be extended to other sectors?

\subsection{International Legal and Regulatory Context}

\subsubsection{United States}

The United States Securities Exchange Commission ("SEC") Regulation S-K sets out materiality based reporting requirements for issues that may affect a company's financial prospects. Stakeholder issues, including consumer campaigns and boycotts, could fall within the scope of this provision. The SEC has interpreted item 303 Regulation S-K (disclosure of known trends, demands, commitment, events or uncertainties that are reasonably likely to affect operational or financial performance) to mean that if there is a reasonable likelihood but some uncertainty about the probabilities regarding such trends, etc., a reporting firm should err on the side of disclosure.

The Sarbanes-Oxley Act of 2002 requires CEO and CFO certification of internal controls that assure the identification of material risks, which could include social risks. Aside

\footnotetext{
${ }^{29}$ Bill C-300, Corporate Accountability of Mining, Oil and Gas Corporations in Developing Countries Act, $2^{\text {nd }}$ Sess., 2009 (as passed second reading April 22, 2009); see also forthcoming bill of Canadian Member of Parliament Rob Oliphant regarding ESG disclosure by pension funds, (September 15, 2009), Press Release online: <http://www.share.ca/files/090915_Oliphant_Pension_Fund_Disclosure_en.pdf> .
} 
from these general requirements, there are few specific ESG disclosure or reporting requirements. This state of affairs, however, may be changing. In response primarily to the climate change debate, the SEC Investor Advisory Committee met with stakeholders in the summer of 2009 to discuss disclosure of ESG issues. In particular, the following issues were discussed:

- Whether investors consider sustainability issues important in making investment or voting decisions;

- Whether current disclosure practices on sustainability are sufficient for investors to make informed investment and voting decisions;

- If additional disclosure would be useful, whether changes are needed in guidance forms or regulations, or in the provision of greater instruction and oversight of disclosure within the current regime.

Some members of the committee have indicated their view that traditional reporting and accounting do not capture many important issues and that broadening disclosure to more meaningfully include ESG considerations would better reflect the real value of an issuer and the risks that they face.

\subsubsection{European Union}

Despite a 2001 "Green Paper" issued by the European Union that emphasized the "voluntary" nature of CSR obligations, the European Union has generally been seen as a "stronghold" for CSR law and policy. This has been said to reflect a more corporatist history of business management within some European Union countries. For example, European jurisdictions have tended to enshrine corporate governance structures that are designed to mediate various competing interests and stakeholder constituencies, giving them a greater role in the management of business. ${ }^{30}$

\footnotetext{
${ }^{30}$ Kerr, Janda, Pitts at 566. 
While the effectuation of CSR law and policy generally, and corporate social performance disclosure obligations in particular, is done primarily at the national level, the European Community has supported "triple bottom line" reporting and detailed environmental disclosure. In 2002 the European Union adopted the Accounts Modernisation Directive (2003/51/EC) which advised member states to require financial reporting to include risk assessments that take into consideration non-financial key performance indicators including information relating to environmental and employee matters.

\subsubsection{France}

In 2001, mandatory corporate environmental and social disclosure was legislated in France. French corporations listed on the Premier Marché are required to annually report on the social and environmental impact of their activities. Social and community factors that must be disclosed include:

- $\quad$ recruitment and workforce utilization;

- use of permanent versus temporary labour or subcontracted labour;

- overtime;

- staff reductions and employment safeguard plans;

- work hours;

- wages and welfare costs;

- gender parity in wages and benefits;

- industrial relations;

- health and safety conditions;

- integration of disabled workers;

- territorial impact;

- community relationships;

- community development. 
The legislation has been criticized for lacking sanctions for non-compliance. A 2003 study found that two thirds of listed French companies reported on only $40 \%$ of the required indicators. A 2005 study indicated that reporting practices had improved. ${ }^{31}$

\subsubsection{United Kingdom}

In 2006, new environmental and social reporting requirements for U.K. based public companies were introduced as part of the Companies Act, 2006. Directors' statutory duties were modified to require them to consider the company's effects on a range of social and environmental matters. ${ }^{32}$ As part of the mandatory "business review" that forms part of annual financial reporting, companies must report on their social and environmental risks and opportunities for their shareholders, as well as on employee matters and risks down supply chains. ${ }^{33}$ The statute allows companies not to report on social and environmental issues so long as it so states. This broad caveat to social and environmental reporting makes such reporting essentially voluntary. ${ }^{34}$

U.K. legislation also requires trustees of U.K. occupational pension funds to disclose the extent (if at all) to which social, environmental or ethical considerations are taken into account in the selection, retention and realization of investments, and policies regarding rights attached to such investments. Studies have indicated widespread noncompliance with these requirements among U.K. pension plan trustees. ${ }^{35}$

\subsubsection{Norway and Denmark}

Since 1999, Norway's Accounting Act has required company directors in the annual directors' report to report on certain social and environmental issues. Companies are

\footnotetext{
${ }^{31}$ Kerr, Janda, Pitts at 258.

${ }^{32}$ Companies Act, 2006, s. 172.

${ }^{33}$ Ibid., s. 417.

${ }^{34}$ Ibid at 260.

${ }^{35}$ Kerr, Janda, Pitts at 263.
} 
required to provide information on the internal workplace regarding injuries and accidents, absences due to illness, gender equality and discrimination. There are no legislated penalties for non-compliance, and studies have shown that only $10 \%$ of companies comply with the full extent of the disclosure obligations set out in the Accounting Act. $^{36}$

On December 16, 2008, the Danish Parliament adopted the proposed "Act amending the Danish Financial Statements Act (Report on social responsibility for large businesses" (the "Danish Act"). Under the Danish Act, large Danish companies (whether or not listed) must include information on their CSR policies and practices in their annual reports, including disclosure of standards, guidelines or principles; how such policies are being implemented (including monitoring and compliance systems), and achievements resulting from CSR work during the financial year, and any related future implications for the company. ${ }^{37}$ Such information is subject to audit.

\subsubsection{South Africa}

Following initial recommendations from the King Committee on Corporate Governance in 2002, all companies with securities listed on the Johannesburg Securities Exchange, financial entities, public sector enterprises and agencies are now subject to the principles stipulated in a Code of Corporate Practices and Conduct. This code requires applicable companies to report annually on the nature and extent of social, transformation, ethical, safety, health and environmental management policies and practices. The determination of relevance is left to corporate boards to consider in light of the particular circumstances of the company and is intended to promote stakeholder engagement (and trust) and better risk management. Compliance with the code is not mandatory, but companies are required to report the extent of their compliance. This allows for market and public evaluation of corporate reporting practices. The code

\footnotetext{
${ }^{36}$ Ibid. at 264.

${ }^{37}$ Ibid at 265.
} 
places emphasis on issues such as economic empowerment, HIVIAIDS awareness and other non-financial information of particular relevance South African society. ${ }^{38}$

A third King Committee report was released in 2009 ("King III"). King III recommends integrated sustainability performance and integrated reporting to enable stakeholders to make a more informed assessment of the economic value of a company. The integrated report should have sufficient information to record how the company has positively and negatively impacted on the economic life of the communities in which it operated during the year under review. Further, it should report how the board believes that in the coming year it can improve the positive aspects and eradicate or ameliorate the negative aspects, in the coming year. ${ }^{39}$

\section{Questions:}

- To what extent should practices of other jurisdictions influence Canadian securities regulators?

- In light of these international examples, should Canadian securities and corporate laws be changed to encourage and enhance disclosure requirements?

- Should stock exchanges or other appropriate standard setters play a role in promoting social performance measurement and disclosure, and if so what should it look like?

- Are there competitive advantage/disadvantage issues at play that should be considered in considering whether to legislate or otherwise promote further disclosure requirements?

\footnotetext{
${ }^{38}$ Ibid at 262.

${ }^{39}$ King Code of Governance for South Africa (2009), online:

$<$ http://www.iodsa.co.za/downloads/documents/King\%20Code $\% 20$ of $\% 20$ Governance $\% 20 f o r \% 20$ SA $\% 20$ 2009.pdf>.
} 


\section{Supranational Initiatives}

\subsection{United Nations}

\subsubsection{Global Compact}

The Global Compact is structured as a voluntary governance initiative between the UN and corporate participants and exists to assist the private sector in the management of increasingly complex risks and opportunities in the environmental, social and governance realms. The Global Compact provides a policy framework for the development, implementation, and disclosure of sustainability principles and practices, as encompassed by ten principles:

\section{Human Rights}

- Principle 1: Businesses should support and respect the protection of internationally proclaimed human rights; and

- Principle 2: make sure that they are not complicit in human rights abuses.

\section{Labour Standards}

- Principle 3: Businesses should uphold the freedom of association and the effective recognition of the right to collective bargaining;

- Principle 4: the elimination of all forms of forced and compulsory labour;

- Principle 5: the effective abolition of child labour; and

- Principle 6: the elimination of discrimination in respect of employment and occupation.

\section{Environment}

- Principle 7: Businesses should support a precautionary approach to environmental challenges;

- Principle 8: undertake initiatives to promote greater environmental responsibility; and 
- Principle 9: encourage the development and diffusion of environmentally friendly technologies.

\section{Anti-Corruption}

- Principle 10: Businesses should work against corruption in all its forms, including extortion and bribery.

The Global Compact incorporates a policy known as the Communication on Progress ("COP") that requires the annual posting by corporate participants of information regarding Compact issue areas. Participating companies are required to follow this policy, as a commitment to transparency and disclosure is critical to the success of the initiative. Failure to communicate will result in a change in participant status and possible delisting from the Compact. ${ }^{40}$

\subsubsection{UNEP FI Asset Management Working Group}

The AMWG was formed in 2003 with the purpose of advancing the integration of ESG factors into investment decision-making. A significant theme in its research and its findings is the need for more detailed and more standardized corporate reporting on ESG performance. The AMWG's first major report, The Materiality of Social, Environmental and Corporate Governance Issues to Equity Pricing, noted that "[t]he majority of analysts noted difficulties in comparative analysis due to the range of reporting practices for environmental, social and corporate governance risks and opportunities." One of the key findings of the report is that inadequate reporting is often a barrier to ESG analysis, and in the report the AMWG calls on regulatory bodies to "update financial disclosure regulations for companies and stock exchanges to require specific disclosure of environmental, social and corporate governance criteria."41

\footnotetext{
40 "Overview of the UN Global Compact" (2009), online: Global Compact $<$ http://www.unglobalcompact.org/AboutTheGC/>.

41 "The Materiality of Social, Environmental and Corporate Governance Issues to Equity Pricing" (2004), online: AMWG < http://www.unepfi.org/work streams/investment/amwg/> at p. 5.
} 


\subsubsection{United Nations Conference on Trade and Development}

The United Nations Conference on Trade and Development ("UNCTAD"), through the International Standards of Accounting and Reporting ("ISAR") working group, has also done extensive work in the area of corporate social performance reporting. ISAR has conducted a number of studies on corporate responsibility reporting practices. The most recent of these was a 2008 review of corporate responsibility reporting which examined the reporting practices of 100 enterprises from 10 emerging markets. This study was complemented by a 2008 review of the corporate responsibility performance of large emerging market enterprises. In November 2008, UNCTAD signed a Memorandum of Understanding with the Global Reporting Initiative (discussed below). This new initiative is aimed at promoting in developing countries and transition economies greater understanding of, and greater participation in, the processes that set internationally recognized sustainability reporting standards.

\subsection{Other Voluntary Initiatives}

During the last several years there have emerged a number of initiatives and organizations that are either investor or issuer led and that address corporate social performance reporting. A few of these initiatives are outlined below.

\subsubsection{Global Reporting Initiative}

The Global Reporting Initiative ("GRI") is an independent, multi-stakeholder network which has developed a voluntary sustainability reporting framework. Launched in 1997, the GRI Framework was developed (and continues to evolve) via a multi-stakeholder process involving industry, investors, civil society and labour, and has emerged as the de facto standard for CSR reporting. It comprises universally-applicable reporting principles, guidance and indicators for organisations of all sizes and sectors. The GRI has also developed sector supplements, including for the mining and metals sector, to help standardize reporting criteria and indicators to the operational context of specific industries. The GRI is followed by over 1,500 companies globally. The GRI has also 
played a role in government legislation of corporate social performance reporting. In 2007 the Swedish Government announced that all Swedish state owned companies must file an annual sustainability report based on the GRI "G3" guidelines each year beginning in 2009.

The GRI's reporting framework sets out principles and indicators that organizations can use to measure and report their economic, environmental, and social performance. Under the GRI "material information" covers topics and indicators that reflect the organization's significant economic, environmental and social impacts or that would substantively influence the assessments and decisions of stakeholders. The GRI does not evaluate the accuracy of reports and has no enforcement mechanisms.

\subsubsection{Extractive Industries Transparency Initiative}

The Extractive Industries Transparency Initiative ("EITI") is a multi-stakeholder initiative that aims to bring about greater transparency regarding the payment of taxes and royalties by resource extraction companies. Specifically, the initiative calls for the regular publication of payments made by companies to governments and revenues governments receive from companies; independent auditing and reconciliation using international standards; the involvement of civil society in design, monitoring and evaluation; and the development of a public and financially sustainable work plan by each host government.

Investors, especially institutional investors, have been integral stakeholders and participants in the EITI. Recognizing that enhanced transparency can mitigate investment risk in the extractive industries, over 80 institutional lenders and investors, representing US\$16 trillion, have officially endorsed the initiative and signed the Investors' Statement on Transparency in the Extractives Sector, which calls on companies to support the principle of payments disclosure and to work proactively with host country governments and other stakeholders to promote, develop and implement transparency agreements. 


\subsubsection{Equator Principles}

The Equator Principles ("EPs") are a set of 10 principles for managing environmental and social risks in project finance. The EP were negotiated and developed by banks with participation from other relevant stakeholders. The EPs were first agreed to in June, 2003, by 10 banks and subsequently revised in 2006. From 2003 to 2006, over 40 additional financial institutions signed on to the EPs. As of April 30, 2009, 67 financial institutions had adopted the EPs, including all of the five major Canadian banks.

The EPs act as a baseline or minimum benchmark for each member institution's own internal social and environmental policies, procedures and standards. A primary goal of the EPs is to "avoid the negative impacts on project-affected eco-systems and communities and, if impacts are unavoidable, to minimize effects or appropriately compensate for them". The EPs apply to projects across all industry sectors with a capital cost of US\$10 million or more. They also affect member institutions' advisory activities, purporting to make clients aware of the content, application and benefits of applying the EPs to an anticipated project.

\subsubsection{AccountAbility's AA1000 Standard}

AccountAbility's AA1000 ("AA1000") series are principles-based standards that can be used by any type of organization from multinational businesses, to SMEs, governments and civil society organizations. The standards were developed through multistakeholder consultation processes. The AA1000 AccountAbility Principles Standard 2008 provides a framework for an organization to use in order to identify, understand, prioritize and respond to sustainability challenges. The AA1000 Assurance Standard 2008 is a leading international standard used to provide assurance on publicly available sustainability information, particularly CSR/Sustainability reports. The AA1000 
Stakeholder Engagement Standard 2005 provides a framework to help organizations with respect to stakeholder engagement processes. ${ }^{42}$

\subsubsection{ISO 26000}

The ISO established a working group in 2005 to develop a standard setting out guidelines on CSR practices. The objective was to produce a guidance document, written in plain language that is understandable and usable by non-specialists, and not a specification document intended for third party certification. The new standard has been designed to co-exist with, and not replace, existing inter-governmental agreements such as the United Nations Universal Declaration of Human Rights, and those adopted by the International Labour Organization. To this end the ISO has engaged in a process to receive input by stakeholders with a serious interest in CSR and corporate social performance including: industry, government, labour, consumers, nongovernmental organizations, in addition to geographical and gender-based balance. The standard is targeted for final publication in $2010 .^{43}$

\section{Questions:}

- Are voluntary initiatives, such as those outlined above, sufficient to meet the needs of shareholders and other relevant stakeholders for corporate social performance disclosure?

- Can or should regulators mandate or promote private voluntary frameworks for corporate social performance reporting and disclosure?

- Should public or private enforcement mechanisms be considered to promote the consistent implementation of corporate social performance measurement and reporting?

\footnotetext{
${ }^{42}$ Supra note 15.

${ }^{43}$ Online: International Standards Organization <www.iso.org/sr>
} 


\section{Options for Reform}

Should reform of the existing regulatory and governance structure be found appropriate, the question becomes how this might be done. Based on the foregoing review, options for reform might include:

\subsection{Enhanced Reporting Requirements}

If existing disclosure requirements are deemed to be inadequate, Canadian securities regulators could craft new regulatory requirements for enhanced disclosure and reporting on corporate social performance by issuers of securities. The definition of "materiality" could be expanded to include indicators of corporate social performance. The existing disclosure requirements on large financial institutions that are required to publish annual Public Accountability Statements (see Section 3.4.1) could be used as a model for other securities issuers.

To effectuate such an approach, internal and external compliance monitoring systems could be put in place. Sanctions, penalties or other consequences for non-compliance could be implemented. This regulatory approach could be coupled with the amendment of non-securities legal and regulatory regimes affecting the corporation. This could include clarification of the scope of directors' and trustees' duties, and/or disclosure requirements for companies in respect of their employment, human rights, health and safety, or other practices that relate to corporate social performance.

As noted above, an important question would be the extent to which reporting requirements would be specifically prescribed, or whether only principles should be promulgated and actual decisions regarding materiality left to the entities themselves. 
The summary by Eugene Ellmen of the Social Investment Organization, at Appendix B attached, describes two different proposals in this regard.

\subsection{Enhanced Compliancel Enforcement with respect to Existing Disclosure Requirements}

If it is concluded that the existing definition of "materiality" for the purposes of Canadian securities law is adequate, then any shortfall in the disclosure of corporate social performance would simply be due to a lack of clarity on expectations, or lack of effective compliance/enforcement. In such a scenario, another option would be to enhance compliance/enforcement mechanisms, and the explanation of disclosure and reporting expectations within the existing scope of "materiality". This could be done through the clarification of disclosure expectations. Increased monitoring of disclosure practices, and the imposition of sanctions or penalties for non-compliance, could also be pursued to encourage enhanced disclosure.

\subsection{Promotion of Voluntary Best Practices}

Securities regulators or other governmental authorities could encourage voluntary adoption of enhanced reporting and disclosure by promoting best practices within the existing regime. This could resemble the CSR "centre of excellence" that is to be created by the Government of Canada (see Section 3.4.2) or endorsement of efforts such as the GRI. It could also involve the issuance of guidelines or the amendment of forms to instruct securities issuers on the proper reporting and disclosure of corporate social performance, within the existing definitions of "materiality". This could be coupled with enhanced compliance/enforcement, or could be purely voluntary in nature. Alternatively, incentives for enhanced corporate social performance disclosure and reporting could be developed. 


\subsection{Enhanced Investor Disclosure Requirements}

Regulators could also establish enhanced disclosure and reporting requirements for investors themselves. In particular, institutional investors and pension funds could be required to publicly report on their investment practices, and the extent to which they use corporate social performance as an indicator for investment decisions. As with other options for reform, the question would be the extent to which disclosure would be prescribed or left up to the institutional investors and what consequences should exist for non-compliance.

\section{Questions:}

- Is reform of the current regime needed to enhance corporate social performance disclosure?

- What other options for reform are there?

- Which options should be acted upon?

- How should reform be carried out?

- To what extent are the initiatives discussed in sections 4.4, 4.5, 5.1 and 5.2 useful as models or components of reform?

- What are the benefits, risks and challenges associated with any attempts at reform?

- For issuers?

- For investors?

- For other stakeholders?

- Would it make sense to promote the creation of a "commission" on corporate social reporting with a view to advancing initiatives that can drive change?

- If so, where should it emerge from and how broad of a mandate might such a body be given? 


\section{Contact us}

If you have any questions or comments, please contact:

\section{Ed Waitzer}

Director, Hennick Centre for Business and Law

Tel: 416.869 .5587

EWaitzer@schulich.yorku.ca

\section{Kevin Ranney}

Global Director, Responsible Investment Services, Jantzi-Sustainalytics

Tel: 416.861 .0403

KRanney@jantzisustainalytics.com

\section{Archana Sridhar}

Associate Director, Hennick Centre for Business and Law

Tel: 416.736 .5490

asridhar@osgoode.yorku.ca 


\section{Appendices}

Appendix A - Laurel Broten resolution

Appendix B - "Mandated ESG Disclosure: A discussion paper on current proposals for regulatory reform" (executive summary), by Eugene Ellmen of the Social Investment Organization - see separate PDF. 


\section{Appendix A - Laurel Broten resolution}

On April 9, 2009, the Ontario legislature voted unanimously to support a private member's resolution introduced by Liberal MPP Laurel Broten (Etobicoke-Lakeshore). The non-binding resolution calls on the OSC to conduct a consultation into best practices on corporate social responsibility (CSR) and environmental, social and governance (ESG) reporting standards. The resolution reads:

Be it resolved that, in the opinion of this House, the province of Ontario should undertake a review of Ontario's current corporate disclosure reporting requirements, standards and compliance therewith, with a particular emphasis on additional financial and non-financial information to ensure that Ontario investors have access to all information material to them in making investment decisions.

That, in undertaking such a review, the Ontario Securities Commission (OSC) should undertake a broad consultation with its own advisory bodies including the Continuous Disclosure Committee, concerned stakeholders, appropriate interest groups and individuals and other securities regulators, to establish best practice corporate social responsibility (CSR) and environmental, social and governance (ESG) reporting standards.

That the OSC seek to develop and adopt an enhanced standardized reporting framework for both quantitative and qualitative social and environmental information to ensure corporate disclosures are understandable, comparable and outcome-focused.

That the OSC shall report back to the Minister of Finance no later than January 1,2010 , with regard to its findings, together with recommendations for next steps to enhance disclosure. 